Brit. J. Psychiat. (1977), 130, 520-4

\title{
Correspondence
}

Letters for publication in the Correspondence colunns should be addressed to:

The Editor, British Journal of Psychiatry, 17 Belgrave Square, London SW IX 8PG

\section{SZASZ ON SCHIZOPHRENIA}

DEAR SIR,

I should like to reply to Professor Roth's criticism of my views on schizophrenia (Journal, October 1976 , 129, $\mathrm{p}$ 317).

I have emphasized that, since Virchow, the most basic and rigorous definition of disease has been the pathological one. Professor Roth does not refute this. Instead, he dwells on the history and empirical value of clinical diagnosis. This is his dichotomy, not mine. I accept the clinical diagnosis of schizophrenia for what it is: attaching a medical-diagnostic label to a phenomenon that looks-to many people-like a disease. I insist, however, that there is, at present, no neuropathological or neurochemical diagnosis that can, in the clinical laboratory or at autopsy, be correlated with it. When (and if) there will be one, then schizophrenia, too, will be a disease. Professor Roth has in no way refuted this simple, but I think important, argument.

Professor Roth writes that 'Of course, if illness is a matter of lumps, lesions, and germs most schizophrenics are perfectly healthy.' That is precisely the point I am making. Psychiatry, Professor Roth then notes, is 'primarily concerned with mental suffering .... That, precisely, is why I contend that psychiatry is not a branch of medicine. Mental suffering is, of course, no less real than cancer or heart disease, but that does not, in my opinion, make it a disease. To be sure, the boundaries of what constitutes disease may be expanded, just as the boundaries of a country may be expanded. That, precisely, is why I contend that men like Kraepelin, Bleuler, and Freud were psychiatric conquistadors rather than medical scientists.

I do not, as Professor Roth writes, believe that the so-called schizophrenic is simply the victim of persons or groups that 'conspire' against him. On the contrary, I have made it abundantly clear that 'mental patients' (especially those said to be suffering from psychoses) are often nasty and troublesome people who coerce or even injure others, thus inviting the counter-coercion called 'psychiatric hospitalization' and 'treatment' ( $\mathrm{I}$ ).
Professor Roth all but ignores the issue of psychiatric coercion, which I consider to be central to the origin, meaning, and function of the concept of schizophrenia. His assertion that in 'Britain nearly all' patients go to the mental hospital voluntarily is, alas, mere psychiatric chauvinism. Furthermore, even if it were true that among all 'civilized' nations, England stood alone unbesmirched by the moral stain of psychiatric slavery, hasn't Professor Roth himself raised his voice against the wholesale use of the diagnosis of schizophrenia as a dispositional weapon against 'dissidents' in the USSR? Hasn't Alexander Solzhenitsyn (2) fully supported the charges I have levelled against institutional psychiatry for all these many decades? Wasn't Ezra Pound imprisoned, without trial, for $13 \frac{1}{2}$ years in the United States Government's model madhouse in Washington, D.C.?

Professor Roth attributes my 'meteoric rise' and 'growing influence and world renown' to my incompetence as an observer and philosopher. That, I submit, impugns and insults the intelligence of the international scholarly and scientific community.

Apropos Professor Roth's remarks about my influence, I should like to call attention to the recent recantations of two of the most prominent psychiatric authorities in the United States. Professor Seymour Kety of Harvard University, whose reputation rests largely on his claim that schizophrenia is a genetic disease (3), told the New York Times on 7 November 1976, that 'Schizophrenia is not a disease, it's an opinion' (4). And Dr Karl Menninger, who, both individually and as a member of a psychiatric clan, has operated a famous American madhouse for the past half-century (in which the most frequent diagnosis, as in all American lunatic asylums, was, presumably, schizophrenia), wrote on 5 November 1976, that 'For one like myself who has always held that there is no such disease as schizophrenia, some articles in this... collection are a bit discomfiting' (5). In 1963, in The Vital Balance, Menninger wrote, apropos schizophrenia and of my views on it: 'We disagree with Szasz on technical and epistemological grounds. We insist that there are conditions best described as mental illness' (6). 
The historical record of psychiatry speaks clearly and loudly: the leaders of this fake medical discipline have a powerful penchant for prevarication and pomposity and are guilty of systematically imprisoning individuals innocent of lawbreaking. I believe, therefore, that my influence is due not to the failings attributed to me by Professor Roth, but to the fact that I tell the truth, call a spade a spade, eschew medicalized coercion, and am willing to defend, in court and out, the victims of psychiatric violence.

Thomas Szasz

Stale University' of Nere Lork,

Upstate Medical Center,

Syracuse, New York I.32IO

\section{References}

1. See, for example, Szasz, T. S. (1973) The Second Sin. Garden City, N.Y.: Doubleday Anchor; London: Routledge, 1974; and Szasz, T. S. (1976) Heresies. Garden City, N.Y.: Doubleday Anchor.

2. Solzhenrtsyn, A. (1976) Warning to the West. New York: Farrar, Straus and Giroux.

3. KetY, S. S. et al (1968) The types and prevalence of mental illness in the biological and adoptive families of adopted schizophrenics. In The Transmission of Schizophrenia (eds D. Rosenthal and S. S. Kety), pp 345-62. Oxford: Pergamon.

4. Quoted in: Hints on the chemical nature of schizophrenia. The New York Times, 7 November 1976, p E-7.

5. Menninger, K. M. (1976) Reading notes. Psychiatric News, 5 November 1975, p 8.

6. - et al (1963) The Vital Balance, p 32. New York: Viking.

\section{PRINATAL PROGEST ERONE}

\section{Dear Sir,}

I refer to Katharina Dalton's article in the Joumal, November 1976, 129, p 438, 'Prenatal progesterone and educational attainments'. There seems good evidence for the statement that 'pre-eclampsia is overwhelmingly a disease of the first pregnancy' ( 1 ). There is also some evidence that first-born excel in educational attainments (2). Might not these factors be a partial explanation for the findings of increased educational attainment in children who had been exposed in utero to progesterone as treatment for their mothers' pre-eclampsia? It would be interesting to know how many of Katharina Dalton's sample were first-born.

3 Harrison Street,

Gary J. Barnes

Cremorne, NSW 2090

\section{References}

1. Ghesley, L. C. (1971) In Williams' Obstelrics, 14th edition (eds Hellman and Pritchard), p 689. New York: Appleton Century Ciroft.

2. Altus, W. D. (1967) Birth order and its sequelae. International Fournal of Psychiatry, 3 (1), 23-9.

\section{'ANOTHER STYLE OF PSYCHOGERIATRIC SERVICE'}

DeAr Sir,

Drs Baker and Byrne (Journal. February 1977, 130, pp 123-6) are to be congratulated on the development of their psychogeriatric day services. These developments are desirable, but the authors' conclusions, we feel, are misconceived.

We think that they have presented an incomplete picture, and it is unfortunate that in making such far-reaching recommendations no reference is made to other published reports in this same field.

There is no mention of joint assessment of patients by Psychiatrist and Physician in Geriatric Medicine, or reference to the number and type of hospital beds and other facilities provided by General and Geriatric Medical services in the area. There is no mention of the provision of residential accommodation by the Local Authority Social Services Department, nor of its policy with regard to the mentally frail. These omissions are vital to the argument, since Andrews and his colleagues have clearly shown that in providing for the elderly it is the total provision of specialized accommodation that matters, including that provided in hospital by the General Medical, Geriatric and Psychiatric services as well as in residential homes.

Implicit in the report is a high degree of seleciivity of patients to be admitted, in that, according to the authors, plans for discharge within a few weeks arc agreed prior to admission.

In most areas of the country there are large numbers of elderly patients with predominantly psychiatric disorders who, even with the most sophisticated community services, still require twentyfour hours care and supervision.

Is it possible that in Gloucestershire the geriatric and other hospitals are providing the care for these patients, who appear to be ignored in this report? Indeed, AHA hospital statistics indicate that there is a relatively generous provision of such beds in the Cheltenham and Gloucester area.

Only 5 per cent of admissions, a remarkably low figure, are discharged from the in-patient beds to 'other' unspecified hospitals. If we compare these clains with previous published studies of hospital 